Western University Scholarship@Western

Aboriginal Policy Research Consortium International (APRCi)

2006

\title{
Suicide in Siberian Aboriginal Groups
}

David Lester

Follow this and additional works at: https://ir.lib.uwo.ca/aprci

Part of the Medicine and Health Commons

Citation of this paper:

Lester, David, "Suicide in Siberian Aboriginal Groups" (2006). Aboriginal Policy Research Consortium International (APRCi). 181. https://ir.lib.uwo.ca/aprci/181 
This article was downloaded by: [University of Western Ontario]

On: 09 December 2012, At: 07:29

Publisher: Routledge

Informa Ltd Registered in England and Wales Registered Number: 1072954 Registered

office: Mortimer House, 37-41 Mortimer Street, London W1T 3J H, UK

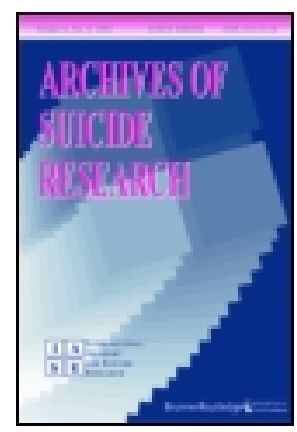

\section{Archives of Suicide Research}

Publication details, including instructions for authors and subscription information:

http:// www. tandfonline.com/loi/ usui20

\section{Suicide in Siberian Aboriginal Groups}

David Lester

Version of record first published: 15 Aug 2006.

To cite this article: David Lester (2006): Suicide in Siberian Aboriginal Groups, Archives of Suicide Research, 10:2, 221-224

To link to this article: http:// dx. doi.org/ 10.1080/13811110600558307

\section{PLEASE SCROLL DOWN FOR ARTICLE}

Full terms and conditions of use: http://www.tandfonline.com/page/terms-andconditions

This article may be used for research, teaching, and private study purposes. Any substantial or systematic reproduction, redistribution, reselling, loan, sub-licensing, systematic supply, or distribution in any form to anyone is expressly forbidden.

The publisher does not give any warranty express or implied or make any representation that the contents will be complete or accurate or up to date. The accuracy of any instructions, formulae, and drug doses should be independently verified with primary sources. The publisher shall not be liable for any loss, actions, claims, proceedings, demand, or costs or damages whatsoever or howsoever caused arising directly or indirectly in connection with or arising out of the use of this material. 


\title{
Suicide in Siberian Aboriginal Groups
}

\author{
David Lester \\ A search of historical documents about suicide in Siberian tribes in the 18th and \\ 19th centuries indicated that they had very high suicide rates. It would be of great \\ interest to explore suicidal behavior in these tribes today.
}

Keywords Siberia, chukchee, suicide

Lester and Kondrichin (2003) studied the regional variation of suicide rates in oblasts, krais and Republics in modern Siberia. The average suicide rate in these regions was 47.2 per 100,000 per year in 1997 , very high compared to other nations.

Modern Siberia is populated by the original ethnic groups who lived there centuries ago, together with the immigrants (and mass deportations) from other parts of the old Soviet Union and the modern Russian Federation. It is of interest to ask, therefore, what was the suicidal behavior of the original ethnic groups who populated Siberia. Are the currently high suicide rates found in both the immigrants to the region and the aboriginal tribes?

The Human Relations Area Files (HRAF) is a project which takes reports from anthropologists, bureaucrats, missionaries and travelers to ancient cultures from around the world and codes the content for various behaviors and customs. For Siberia, data on suicide are available in the HRAF for the Gilyak in Southeastern Siberia and the Chukchee, Koryak, and Kamchadal in Northeast Siberia.

In the past, several researchers have read the reports of suicide in primitive societies and tried to estimate the incidence of suicide in the societies. Masumura
(1977) rated 35 primitive societies from around the world on a scale of 2 to 8 and the Chukchee were given a score of 8 , indicating the highest suicide incidence possible. Palmer (1965) rated 40 primitive societies from around the world on a scale of 0 to 21 and the Chukchee were given a score of 15 , ranking 5 th of the 40 primitive societies. Ember and Ember (1992) rated 186 primitive societies from around the world on a scale of 1 to 3 and the Chukchee were given a score of 2.5 (for reports from the year 1900) while the Gilyak received a score of 2 (for reports from the year 1890). Overall, therefore, the Chukchee appear to have had high suicide rates around the end of the 19th century.

Let us look at the reports themselves.

The Chukchee

Bogoras (1975) reported on suicide among the Chukchee in the period 1890 1901, and he noted that they have a strong inclination towards suicide: "You know our people.... For any reason they want to kill another man or themselves" (p. 46). Bogoras described the Chukchee as irritable and obstinate and, when frustrated, impulsively self-destructive. He reports the case of a young girl who hung herself 
because her mother refused to take her to a feast in a neighboring camp.

Bogoras reported cases of suicide in a husband over grief at his wife's death and of a mother after her ten-year-old son's death; a case motivated by bad fortune, compounded by the fear of further bad fortune; a woman who no longer found any pleasure in life; a young man who was driven away by his father-in-law for being lazy who then killed his pregnant wife and himself; and a young woman whose husband wanted to lend her to a friend in a group marriage, a friend whom she disliked.

Suicidal behavior appeared to be so common that people planning to kill themselves would often ask for a last meal of exotic tastes before they did so. Some Chukchee prefer to commit suicide by having someone else kill them. The man reported above who committed suicide because of present and anticipated misfortune asked to be strangled. In another case, a man who fell ill asked his wife to shoot him. Bogoras noted that "voluntary death" as he called it, suicide by getting others to kill oneself, was common for the elderly and those suffering from physical illnesses. However, Bogoras also noted "peculiar" causes of voluntary death, such as that of a man who grew weary of quarrelling with his wife over their ill-behaved sons. Part of the motive in these cases may be to induce guilt in the survivors. As one father said, "Then he asks to be killed, and charges the very son who offended him with the execution of his request. Let him give me the mortal blow, let him suffer from the memory of it" (p. 561).

Bogoras noted that younger suicides do so by their own hands, whereas older suicides tend more often to ask others to kill them. For the older Chukchee, death by violence is thought to be preferable to death from disease or old age. The term for voluntary death in their language means "single fight." Bogoras also noted that voluntary death tended to run in families, so that the sons of fathers who committed suicide in this way did so themselves eventually. It is not obligatory, but rather a tradition. Those who die in this way are thought to have the best dwelling places in the afterlife. Although friends and relatives will help such a person commit suicide, they do not like to do so, and they usually try to talk the person out of it. The traditional methods are stabbing, strangulation and shooting, although shooting is much less common and less traditional. For stabbing, the blow must be struck by men and not by women, and it is preferable to use the knife of the would-be suicide, with the blow delivered by the son rather than by a stranger. For strangulation, women may assist, for example, by holding the hands of the suicide.

\section{The Koryak and Kamchadal}

The HRAF also has a few notes on suicide in the Koryak and the Kamchadal, also in Northeast Siberia.

Regarding the Koryak, Jochelson (1908), writing about them in the years 1900-1901, noted that they do not fear death and may commit suicide after the death of a relative or after quarrels. In one case, a man who was grieving over the death of his wife, entered the tent after her cremation, sharpened his knife, told his relatives to divide his property amongst themselves and went outdoors, whereupon he stabbed himself in the chest. He missed his heart and recovered. His relatives railed at him that he had not really meant to kill himself.

Krasheninnikov (1764), commenting on suicide in Kamchadal in 1736-1740, noted that they had a strong desire to lead a pleasurable life. They considered it more reasonable to die than to lead a disagreeable life, and so they frequently committed suicide. After Russia conquered the region, the Russians had great difficulty putting a stop to this practice. 
The Kamchadal also committed suicide en masse if they were facing defeat in battle. Initially, they would bravely defend themselves. However, if the battle turned against them, they would first kill their women and children (by slitting their throats) and then throw themselves off the precipice from which they were fighting or else rush into the enemy trying to kill as many as they could before dying.

\section{The Gilyak}

There are also some reports on suicide among the Gilyak. Shternberg (1999) reported on the Gilyak for the period 1890-1897. Shternberg noted that shame and disgrace were very difficult for the Gilyak to endure. For example, a Gilyak who is convicted of a crime such as theft will often go and hang himself. The Gilyak did not commit suicide because of poverty or physical suffering, but only in response to shame and also strong personal grief. If other members of the community are thought to have driven the individual to suicide, then revenge is exacted, but usually payment of a "ransom" (or infliction of property damage) sufficed. The spirits of suicides (as well as those of murder victims) were thought to go to heaven directly, rather than to intermediate places on the way to heaven.

Although the Gilyak were sexually promiscuous by modern Western standards, incestuous relationships were forbidden and, if lovers broke the incest rules, then their parents encouraged them to commit suicide. On some occasions, the lovers would hang themselves side by side in the forests. (Shternberg noted that, if one of the lovers fell from the tree and lived, then he or she might lose the desire to try again to commit suicide!)

Some women were married to men in return for bride prices or betrothals arranged at birth for monetary reasons.
If the bride disliked her husband, she might try to escape but, if this failed (she could be returned to him by her parents, for example), then suicide was not uncommon. ${ }^{1}$

\section{DISCUSSION}

It is interesting to note from these historical documents that suicide was very common in the Chukchee (and, to some extent, in the other tribes) in the distant past. The motives for suicide in the Chukchee seem to include two of the major motives for suicide enumerated by Menninger (1938). The desire to end a tiresome or painful life (what Menninger called "to die"), and the desire to inflict guilt on others ("to kill"), but not depression or guilt ("to be killed"). Interestingly, the major motive for suicide in the Gilyak appeared to be the motive missing in the Chukchee, for the Gilyak frequently killed themselves for reasons of shame and guilt.

The existence of old records of suicide among some of the ethnic tribes in Siberia in the 18th and late 19th centuries suggests that it would be of great interest to examine suicidal behavior in the individuals today. Do they continue to have high rates of suicide (especially the Chukchee) and are the motives and the circumstances of the suicide (such as "voluntary death") similar to those of the past? Other aboriginal groups, such as Native Americans and Native Canadians, have very high suicide rates in modern times (Lester, 1997), and it would be of interest to explore this in modern Siberia.

\footnotetext{
${ }^{1}$ Although most of the examples given by Shternberg involved hanging, there are instances today of suicide by shooting. For example, one woman, interviewed in 1995, remembered her brother shooting himself at the age of 17 because of unrequited love, and she recalled other members of her family committing suicide by shooting (Shternberg, 1999, p. 198).
} 


\section{AUTHOR NOTE}

Correspondence concerning this article should be addressed to David Lester, The Richard Stockton College of New Jersey, Psychology Program, P. O. Box 195, Jimmie Leeds Road, Pomona, NJ, 08240-0195, USA. E-mail: lesterd@ stockton.edu

\section{REFERENCES}

Bogoras, W. (1975). The Chukchee. New York: AMS. Ember, C. R. \& Ember, M. (1992). Warfare, aggression, and resource problems. Behavior Science Research, 26, 169-226.
Jochelson, V. I. (1908). The Koryak. New York: G. E. Stechnert.

Krasheninnikov, S. P. (1764). The bistory of Kamtschatka, and the Kurilski Islands, with the countries adjacent. Gloucester, UK: R. Raikes.

Lester, D. (1997). Suicide in American Indians. Commack, NY: Nova Science.

Lester, D., \& Kondrichin, S. (2003). Suicide and homicide in Siberia. Siberica, 3, 103-107.

Masumura, W. T. (1977). Social integration and suicide. Behavior Science Research, 12, 251-269.

Menninger, K. (1938). Man against bimself. New York: Harcourt, Brace \& World.

Palmer, S. (1965). Murder and suicide in forty nonliterate societies. Journal of Criminal Law, Criminology \& Police Science, 56, 320-324.

Shternberg, L. I. (1999). The social organization of the Gilyak. New York: American Museum of Natural History. 